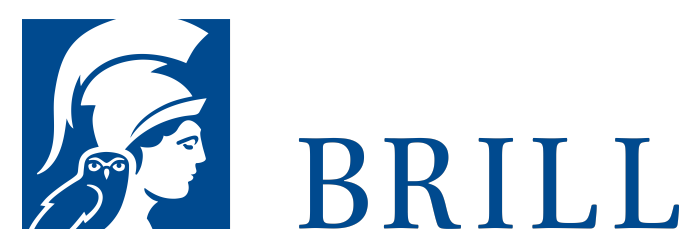

\title{
De Herodoti reliquiis in papyris et membranis Aegyptiis servatis
}

Author: Paap

Language: Latin

Subjects:

General,

Classical Studies

Publisher: Brill

Series:

Papyrologica

Lugduno-

Batava, Volume:

4

E-Book (PDF)

Released online:

O2 Mar $202 \mathrm{O}$

ISBN: $978-90-$

04-42994-9

List price

USD $\$ 42.00$

Hardback

Publication date: o1 Jun 1948

ISBN: 978-90O4-42879-9 
For more information see brill.com

Order information: Order online at brill.com +44330 333 0049 | customerservices@brill.com Submission information: brill.com/authors

Titles published by Brill | Fink, Brill | mentis or Brill | Schöningh: +49(o)715413279216| brill@brocom.de 